\title{
Anti-idiotype antibodies that mimic a conserved aquatic birnavirus epitope induce neutralizing antibodies and bind to fish cells with inhibition of virus replication
}

\author{
S. Y. Chiang, B. L. Nicholson* \\ Department of Biochemistry, Microbiology and Molecular Biology, University of Maine, Orono, Maine 04469, USA
}

\begin{abstract}
Polyclonal anti-idiotype (anti-Id) antibodies were prepared in rats against a monoclonal antibody (MAb AS-1) which defines a highly conserved neutralization epitope on virion protein 2 (VP2) of Serogroup A aquatic birnaviruses. Anti-mouse IgG cross-reactive antibodies were removed from rat sera by adsorption to an affinity column of normal mouse IgG and further purified by subsequent adsorption to and elution from an affinity column coupled with MAb AS-1. Confirmation that these anti-Id antibodies were directed against the paratope of MAb AS-1 and molecularly mimicked the virus epitope was demonstrated in a variety of assays. Anti-Id antibodies reacted in enzyme-linked immunosorbent assay (EL.ISA) with both whole MAb AS-1 IgG and F(ab) ${ }_{2}$ fragments, but did not react with 2 unrelated mouse IgGs or $F(a b)_{2}$ fragments. Anti-Id antibodies blocked binding of virus to MAb AS-1 in a dose-dependent manner with $100 \%$ inhibition at the highest concentration. Similarly, virus inhibited anti-Id/idiotype binding by $60 \%$. Furthermore, anti-Id antibodies inhibited the ability of MAb AS-1 to neutralize virus in plaque reduction assays. Anti-Id antibodies induced the production of virus neutralizing antibodies in mice. Anti-Id antibodies also were used to show that the AS-1 epitope is a presumptive cell attachment site on the virus which recognizes and binds to specific cell receptors. Anti-Id antibodies were shown to bind to a variety of both salmonid and non-salmonid fish cell cultures. Pretreatment of fish cell cultures with virus inhibited ( 28 to $50 \%$ ) binding of anti-Id antibodies. Treatment of fish cell cultures with anti-Id antibodies also resulted in a decrease $(98 \%)$ in the yield of progeny virus compared with replication of the virus in untreated cells or cells treated with normal rat immunoglobulin.
\end{abstract}

KEY WORDS: Anti-idiotype antibodies - Aquatic birnaviruses - Fish cells

\section{INTRODUCTION}

The aquatic birnaviruses are the largest and most diverse group of viruses within the family Birnaviridae and include a variety of viruses from numerous species of fish and marine invertebrates (Wolf 1988). Many of these viruses, such as infectious pancreatic necrosis virus (IPNV), cause different diseases in a variety of species used worldwide in fish farming and aquaculture. Also, aquatic birnaviruses have been isolated from a variety of apparently healthy aquatic and marine species.

-Addressee for correspondence.

E-mail: brucen@maine.maine.edu
Aquatic bimaviruses are characterized by a bisegmented, dsRNA genome within a nonenveloped, icosahedral capsid approximately $60 \mathrm{~nm}$ in diameter (Dobos et al. 1979). The smaller genome segment (B) encodes a single protein (VP1, 90 to $110 \mathrm{kDa}$ ), the virion associated transcriptase. The larger genome segment (A) (approximately $3000 \mathrm{bp}$ ) contains a large open reading frame that encodes a precursor polyprotein $(100 \mathrm{kDa})$ which is subsequently cleaved to form 3 viral proteins (pVP2, $63 \mathrm{kDa}$; NS, $29 \mathrm{kDa}$; and VP3, 29 to $31 \mathrm{kDa}$ ) by protease activity associated with the NS protein (Manning et al. 1990). The pVP2 protein is further processed to yield the major capsid protein VP2 (50 to $55 \mathrm{kDa}$ ). 
The vast majority of aquatic birnaviruses, regardless of host species or geographic origin, are related antigenically and form a major serogroup (Serogroup A) comprised of 9 related but distinguishable serotypes (Hill \& Way 1983, Caswell-Reno et al. 1989, Nicholson 1993). A few antigenically unrelated aquatic birnaviruses represent a second, minor serogroup (Serogroup B).

Previously, we developed and used a library of monoclonal antibodies (MAbs) to demonstrate that some epitopes are highly conserved among this diverse group of viruses whereas others are unique to specific birnavirus serotypes or strains (Anderson 1986. Caswell-Reno et al. 1986, 1989, Lipipun et al. 1989). Presumably, highly conserved epitopes serve a critical structural and/or functional role in virus replication. Several of these MAbs neutralize viral infectivity whereas others bind to virus without resulting neutralization. The specificities of most neutralization epitopes are conformationally dependent. We have mapped all identified neutralization epitopes to the VP2 virion protein (Lipipun et al. 1992). Other than the localization of neutralization epitopes to the VP2 protein, little is known about the nature of the immunogenic structure of these viruses or the mechanisms of antibody-mediated neutralization.

As indicated previously, aquatic birnaviruses are ubiquitous and infect a variety of fish species worldwide with or without production of disease. These viruses also replicate, in vitro, in a variety of fish cell cultures derived from different fish species (Wolf 1988). However, certain isolates or virus strains are incapable of replicating in several of these fish cell cultures. For example, the Ab strain does not replicate in FHM cells (Wolf 1988). Scherrer \& Cohen (1975) and Nicholson et al. (1979) demonstrated that the ability of certain strains to replicate in various fish cell cultures is the result of the continuous production and subsequent selection of in vitro host range variants in the virus population. The cellular and molecular mechanisms that determine the ability of these viruses to infect specific cells or host species are not known. Indeed, virtually nothing is known about the cell receptors for these viruses or the attachment sites on the virion that recognize and bind to these receptors. Such information is important, however, in understanding how these viruses adapt to new host species and possible cell or tissue tropisms that may determine the nature of diseases caused by infection with these viruses

Anti-idiotype (anti-Id) antibodies have been used to investigate viral neutralization epitopes and to develop surrogate viral antigens. As proteins, antibodies can serve as antigens and stimulate the production of antiantibodies. According to the physical relation of idiotopes to the antigen binding site of a given antibody
(Ab1), anti-Id antibodies (Ab2) are classified into at least 3 types. The $\alpha$-type anti-Id antibodies recognize idiotopes distinct from the antigen binding site whereas $\beta$-type anti-Id antibodies react with the antibody combining site for the epitope (paratope). The $\gamma$-type anti-Id antibodies recognize idiotopes close to but not in the paratope (Farid \& Linthicum 1988). Since they are directed against the antigen binding site of the idiotype, the antigen binding site on $\beta$-type anti-Id antibodies will be a reverse image of the idiotype and, therefore, molecularly mimic the 3-dimensional structure of the original antigen epitope. Therefore, $\beta$-type anti-Id antibodies can be used as surrogate antigens. Anti-Id antibodies that molecularly mimic the 3-dimensional structure of viral epitopes have been used as surrogate antigens to stimulate the production of neutralizing antibodies against a variety of viruses, including: rabies virus (Reagan et al. 1983), poliovirus (Uytdehaag \& Osterhaus 1985), human cytomegalovirus (Keay et al. 1988), influenza virus (Anders et al. 1989), bovine herpes virus 1 (Srikumaran et al. 1990, Hariharan et al, 1991), human respiratory syncytial virus (Palomo et al. 1990), and Sindbis virus (Ubol \& Griffin 1991). Theoretically, anti-Id antibodies may provide advantages as vaccines over conventional or even some recombinant DNA based vaccines, including: (1) the lack of risks associated with live pathogens; (2) relatively inexpensive preparation compared to propagation of virus; (3) the fact that anti-Id antibodies mimic the native 3 -dimensional conformation of the antigen and, therefore, may stimulate a better immune response than inactivated or subunit vaccines which may have been altered in antigenicity; and (4) the fact that some anti-Id antibodies have the potential to stimulate both humoral and cellular immunity. There currently is only one, recently licensed (only in Norway), vaccine for the control of diseases caused by aquatic birnaviruses. However, the efficacy of this vaccine for all strains of virus in a variety of fish species is unknown. And, despite this and other work on vaccine development, little is known about the nature of neutralization epitopes or the mechanisms of immune neutralization of these viruses.

Anti-Id antibodies can also be used to investigate the function of specific epitopes. This is particularly true for conformationally dependent epitopes where genetically engineered or synthetic peptides that retain antigenic specificity cannot be prepared. As indicated previously, most neutralization epitopes on aquatic birnaviruses are conformationally dependent. Thus, to date, it has not been possible to investigate the biological function of individual birnavirus epitopes, including the ability to induce virus neutralizing antibodies.

In this report, we describe the production and characterization of polyclonal rat anti-Id antibodies against 
a MAb (MAb AS-1) specific for a universally conserved, conformationally dependent, neutralization epitope on the VP2 protein of aquatic birnaviruses. Furthermore, we show that birnavirus-specific neutralizing antibodies can be induced in mice by immunization with these anti-Id antibodies. We also show that these anti-Id antibodies bind to a variety of fish cell cultures and inhibit virus replication in cell culture.

\section{MATERIALS AND METHODS}

Animals. Female Lou rats (Harlan Sprague Dawley Inc.) were used for producing anti-Id antibodies. Female BALB/C mice (The Jackson Laboratory, Bar Harbor, ME, USA) were used for preparing anti-anti-Id antibodies.

Cell cultures. The following continuous fish cell cultures were used: Chinook salmon embryo cells (CHSE214) (Lannan et al. 1984), rainbow trout gonad (RTG-2) (Wolf \& Quimby 1962), blue gill fry (BF-2) (Wolf \& Quimby 1966), brown bull head (BB) (Cerini \& Malsberger 1962) and Atlantic salmon cells (AS) (Nicholson \& Bryne 1973). All cell cultures were grown at $20^{\circ} \mathrm{C}$ in Eagle's minimum essential medium (MEM; Sigma Chemical Co., St. Louis, MO, USA) with 10\% fetal bovine serum (FBS) (Hyclone Laboratories, Inc., Logan, UT, USA) and $0.2 \%$ sodium bicarbonate (Sigma Chemical Co.) as described previously (Caswell et al. 1986)

Virus. The Atlantic salmon virus (ASV), a member of the $\mathrm{C} 1$ aquatic birnavirus serotype, was propagated in CHSE- 214 cells at $20^{\circ} \mathrm{C}$ with a multiplicity of infection (MOI) of 0.01 to 0.1 as described previously (CaswellReno et al. 1986). Virus was purified as described previously (Caswell-Reno et al. 1989).

Virus quantification. Virus titers were determined as tissue culture infectious dose-50\% (TCID 50 ) as described previously (Reed \& Muench 1938, CaswellReno et al. 1989). Alternatively, total viral protein concentration of purified virus preparations was determined by the method of Johnstone \& Thorpe (1982). The concentration of protein was determined using a Beckman DU-40 spectrophotometer at 280 and $260 \mathrm{~nm}$ using the formula: $\mathrm{mg}$ of protein $\mathrm{ml}^{-1}=\left(1.55 \times A_{280}\right)-$ $\left(0.76 \times A_{260}\right)$, where $A$ is absorbance. Also, an estimate of the approximate number of viral particles in preparations of purified virus was determined according to the method used for reovirus (Smith et al. 1969, Kauffman et al. 1982): $1 A_{260}$ unit corresponds to approximately $2 \times 10^{12}$ viral particles $\mathrm{ml}^{-1}$.

Monoclonal antibody preparation. MAb AS-1 (IgG1, kappa) (Anderson 1984) was prepared as described previously (Caswell-Reno et al. 1989).

Other immunoglobulins (Ig) and normal animal sera. A heterologous monoclonal antibody (G3-395) raised against human chorionic gonadotropin (HCG) of the same isotype as MAb AS-1 (IgG1, kappa) and mouse myeloma protein, MOPC-21 (IgG1, kappa) (Organon Teknika Corporation, West Chester, PA, USA), served as isotype cross reaction controls in certain experiments. Normal sera from mouse, rat, and guinea pig were purchased from Organon Teknika Corporation and used as a supplement for buffer solutions or for adsorption to remove cross-reactivity.

Production of rat anti-Id antibody (anti-Ids). Lou rats were first injected intraperitoneally (i.p.) with $80 \mu \mathrm{g}$ of purified MAb AS-1 mixed with an equal volume of complete Freund's adjuvant. Two booster doses were administrated at $2 \mathrm{wk}$ intervals with $75 \mu \mathrm{g}$ of MAb AS- 1 in incomplete Freund's adjuvant and $50 \mu \mathrm{g}$ in $0.85 \%$ normal saline, respectively. Thereafter, animals were continuously boosted with $50 \mu \mathrm{g}$ of MAb AS- 1 in normal saline at $3 \mathrm{wk}$ intervals. Animals were bled at intervals of about 7 to $10 \mathrm{~d}$ after the previous injection. Blood was allowed to clot at $37^{\circ} \mathrm{C}$ for $1 \mathrm{~h}$ or at $4^{\circ} \mathrm{C}$ for 2 to $3 \mathrm{~h}$ and antisera were then collected by centrifugation at $324 \times \mathrm{g}$ for $20 \mathrm{~min}$ and stored at $20^{\circ} \mathrm{C}$.

Antibody purification. A conventional procedure for MAb purification was followed (Fuller et al. 1989). Hybridoma culture supernatants containing $0.05 \%$ sodium azide were first applied to a goat anti-mouse Ig affinity column by gravity flow and the column washed with buffer (50 mM Tris-HCl, $150 \mathrm{mM} \mathrm{NaCl}, \mathrm{pH} 8.0$ ). Bound antibodies were eluted with $0.1 \mathrm{M}$ glycine $\mathrm{HCl}$ $(\mathrm{pH}$ 2.3), immediately neutralized with phosphate buffer ( $\mathrm{pH}$ 7.2), and dialyzed overnight against phosphate-buffered saline (PBS) at $4^{\circ} \mathrm{C}$. The concentration of purified Ig was estimated from the formula: $\mathrm{mg}$ of protein $\mathrm{ml}^{-1}=A_{280} / 1.4$ (Johnstone \& Thorpe 1982). For anti-Id antibody purification, the protocol described by Ardman et al. (1985) was used. Pooled immunized rat sera were diluted with an equal volume of Tris buffer ( $50 \mathrm{mM}$ Tris- $\mathrm{HCl}, 150 \mathrm{mM} \mathrm{NaCl}, \mathrm{pH} \mathrm{8.0)}$ and passed through an affinity column coupled with normal mouse IgG to remove anti-isotypic antibodies. When necessary, antibody effluent was collected and repeatedly passed through the column one or more times. Adsorbed rat anti-Id serum was subsequently purified by capture on another affinity column coupled with the idiotype antibody (MAb AS-1). The bound anti-Id antibodies were then eluted with $0.1 \mathrm{M}$ glycine- $\mathrm{HCl}$ ( $\mathrm{pH} 2.3$ ), adjusted to a $\mathrm{pH}$ of 7.0 with phosphate buffer (0.5 $\mathrm{M} \mathrm{KH}_{2} \mathrm{PO}_{4}$ and $\left.0.5 \mathrm{M} \mathrm{Na}_{2} \mathrm{PO}_{4}\right)$ (pH 7.2), dialyzed, and the protein concentrations determined as described above. Purified antibodies were stored at $-20^{\circ} \mathrm{C}$.

$\mathbf{F}(\mathbf{a b})_{2}$ fragment preparation. The method for preparing $\mathrm{F}(\mathrm{ab})_{2}$ fragments was performed as described by Paque \& Miller (1989). Briefly, purified MAb prepared in $0.1 \mathrm{M}$ sodium acetate ( $\mathrm{pH} 7.2)$ was adjusted with $2 \mathrm{M}$ acetic acid to $\mathrm{pH} 4.2$ and kept at $37^{\circ} \mathrm{C}$. Pepsin was then 
added to a final ratio of $1: 33(\mathrm{w} / \mathrm{w})$. The mixture was incubated at $37^{\circ} \mathrm{C}$ and the digestion patterns traced by collecting samples at 2 or $4 \mathrm{~h}$ intervals. Pepsin digestion was stopped by increasing the $\mathrm{pH}$ to 7 to 8 with $0.5 \mathrm{~N}$ $\mathrm{NaOH}$ and $2 \mathrm{M}$ Tris- $\mathrm{HCl}, \mathrm{pH}$ 8.0. Digested antibody fragments, including $\mathrm{F}(\mathrm{ab})_{2}$ fragments and partial $\mathrm{FC}$ portions, were dialyzed in PBS at $4{ }^{\circ} \mathrm{C}$ overnight, and the $\mathrm{F}(\mathrm{a} b)_{2}$ fragments were subsequently purified by gel filtration (S-200) (Pharmacia Fine Chemicals) at a flow rate of $20 \mathrm{ml} \mathrm{h}^{-1}$. Protein concentrations were estimated from $A_{280}$ determinations (Johnstone \& Thorpe 1982).

Antibody biotinylation. Purified MAb AS- 1 was diluted in $0.1 \mathrm{M}$ sodium bicarbonate solution $(\mathrm{pH}$ 8.4) and adjusted to a final concentration of $1 \mathrm{mg} \mathrm{ml}^{-1}$. Biotin (Sigma Chemical Co.) was dissolved in dimethyl sulfoxide at a concentration of $1 \mathrm{mg} \mathrm{ml}^{-1}$. MAb AS-1 $(1 \mathrm{mg})$ and biotin $(120 \mu \mathrm{g})$ were mixed in an end-overend mixer. After incubation for $4 \mathrm{~h}$, the conjugates were dialyzed in PBS at $4^{\circ} \mathrm{C}$ (Gaulton et al. 1985, Lamarre et al. 1991).

Production of mouse anti-anti-Id antibody (Ab3). Purified rat anti-Id Ig in normal saline $(20 \mu \mathrm{g})$ mixed with an equal volume of CFA were administered to $B A L B / C$ mice by i.p. injection. Mice were boosted i.p. with $15 \mu \mathrm{g}$ of anti-Id Ig in an equal volume of IFA 2 to 3 wk after the first immunization. Subsequent boosts were made using a mixture of $15 \mu \mathrm{g}$ of anti-Id Ig and normal saline. Blood was collected at various intervals and handled as described previously.

Neutralization tests. Neutralization of ASV by MAb AS-1: Undiluted MAb AS-1 was mixed with equal volumes of 10 -fold serial dilutions of virus and incubated at room temperature for $1 \mathrm{~h}$. A total of $100 \mu \mathrm{l}$ of each mixture were then inoculated onto 4 wells of 96well microtiter plate with monolayers of CHSE-214 cells. After incubation for $7 \mathrm{~d}$, virus titers (TCID 50 ) were calculated by the method of Reed \& Muench (1938).

Neutralization of ASV with mouse anti anti-Id sera (Ab3): Two-fold serial dilutions of mouse anti-anti-Id sera (Ab3) were mixed with an equal volume of ASV (400 $\mathrm{TCID}_{50} \mathrm{ml}^{-1}$ ) and incubated at room temperature for $1 \mathrm{~h}$. Aliquots of each mixture $(100 \mu \mathrm{l}$ per well) were transferred to 3 wells of microtiter plates with CHSE214 monolayers. The $50 \%$ neutralizing dose $\left(\mathrm{ND}_{50}\right)$ of each antiserum was calculated after $7 \mathrm{~d}$ by the method of Reed \& Muench (1938).

Inhibition by anti-Id antibodies of MAb AS-1 virus neutralization: Serial 2-fold dilutions $(250 \mu \mathrm{l})$ of adsorbed rat anti-Id antibody or adsorbed normal rat serum were mixed with an equal volume of MAb AS-1 $\left(2.5 \mathrm{\mu g} \mathrm{ml}^{-1}\right)$ at room temperature for $2 \mathrm{~h}$. A total of 300 $\mu \mathrm{l}$ of ASV containing $600 \mathrm{TCID}_{50}$ was then added and incubated for $1 \mathrm{~h}$. The mixtures were transferred to 12 well plates with monolayers of CHSE-214 cells and incubated at $20^{\circ} \mathrm{C}$ for another hour. The monolayers were washed gently to remove unadsorbed virus and overlaid with $0.8 \%$ agarose in MEM with $5 \%$ FBS. After a $48 \mathrm{~h}$ incubation at $20^{\circ} \mathrm{C}$, the cells were fixed with $10 \%$ formaldehyde in PBS at room temperature and plaques were counted after staining with $2 \%$ crystal violet.

Enzyme-linked immunosorbent assay. Several different types of enzyme-linked immunosorbent assay (ELISA) tests were used in this study. In general, for the majority of tests, $100 \mu \mathrm{l}$ of each test sample were applied to 96 -well microtiter plates. Unbound sites on each well were blocked with 1 or $3 \%$ bovine serum albumin (BSA). After each step, the plates were washed 3 times with PBS ( $\mathrm{pH} 7.4$ ) containing $0.05 \%$ Tween 20. Horseradish peroxidase conjugates (HRPO) purchased from Hyclone Laboratories, Inc. were utilized and visualized by adding the substrate, 2,2' azinobis(3-ethyl benz-thiazoline sulfonic acid) (ABTS, Sigma Chemical Co.) in $0.1 \mathrm{M}$ citrate buffer, pH 4.5 . Results were read by a Titertek Multiscan Photometer at $405 \mathrm{~nm}$ (Flow Laboratories, Irvine, Scotland, UK).

Reaction of MAb AS-1 with ASV: MAb AS-1 (10 $\mu \mathrm{g}$ $\mathrm{ml}^{-1}$ in PBS) was first coated to plates at room temperature for $1.5 \mathrm{~h}$. Virus, diluted to $5 \times 10^{7} \mathrm{TCID}_{50} \mathrm{ml}^{-1}$, was then added to the specific wells for an additional $1.5 \mathrm{~h}$ at $37^{\circ} \mathrm{C}$. After incubation with biotin labeled MAb AS- 1 in $1 \%$ BSA for $1.5 \mathrm{~h}$, avidin conjugated HRPO in $1 \%$ BSA was added, and binding was measured after applying the substrate ABTS.

Demonstration of presumptive anti-id antibody (Anti-Ids): The activity and specificity of presumptive rat anti-Id antibodies were initially tested by a modification of the method of Marriott et al. (1987). Purified MAb AS-1 (IgG1, kappa), or myeloma protein MOPC21 (IgG1, kappa), was prepared in PBS (5 $\left.\mu \mathrm{g} \mathrm{ml}^{-1}\right)$ and used to coat to ELISA plates at room temperature for $1 \mathrm{~h}$. Two-fold serial dilutions of presumptive rat anti-Id antibodies or normal rat serum (NRS) previously mixed with normal mouse serum (NMS) at a ratio of 1:3 at room temperature for $30 \mathrm{~min}$ were added to the plates. After a $2 \mathrm{~h}$ incubation at room temperature, goat antirat Ig peroxidase conjugate at a 1:1000 dilution in 1\% BSA with 5\% FBS and 5\% NMS was then added for another $2 \mathrm{~h}$. Substrate (ABTS) was added for 15 to 30 min and the $A_{405}$ was determined with a Titertek Multiscan photometer.

Specificity of anti-Id antibodies: In order to further confirm that the rat antiserum contained antibodies specific to the Fab portion of MAb AS-1, F(ab) fragments of MAb AS-1 (5 $\left.\mathrm{gg} \mathrm{ml}^{-1}\right)$, or a control MAb (G3-395) of the same isotype, were coated to wells of ELISA plates (Paque \& Miller 1991). After blocking with $200 \mu \mathrm{l}$ of $1 \% \mathrm{BSA}, 100 \mu \mathrm{l}$ of serial 2-fold dilutions of adsorbed rat anti-Id serum in $1 \% \mathrm{BSA}$ were added to the wells coated with MAb AS-1 or G3-395 
antibodies for another $1 \mathrm{~h}$. Biotin-labeled mouse antirat kappa light chain antibodies in $1 \%$ BSA were then added for $1 \mathrm{~h}$, and alkaline phosphatase avidin at a 1:1000 dilution was added for an additional $30 \mathrm{~min}$. Phosphatase substrate (p-nitrophenyl phosphate) (pNPP, Sigma Chemical Co.) in 10\% diethanolamine (pH 9.8) (100 $\mu$ l per well) was added at $37^{\circ} \mathrm{C}$ for 30 min and the absorbance at $405 \mathrm{~nm}\left(A_{405}\right)$ was determined. Alternatively, the specificity of anti-Id antibodies to MAb AS- 1 was determined by collecting adsorbed anti-Id antiserum samples after passing through a normal mouse IgG affinity column and testing for reaction with MAb AS-1 or control antibodies (MOPC-21 or G3-395). Briefly, monoclonal

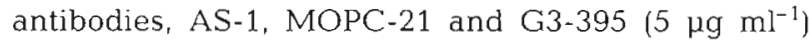
were separately coated to the ELISA plate for $1.5 \mathrm{~h}$. Collected anti-Id samples were diluted $1: 50$ in $1 \%$ BSA and added to the plates for another $1.5 \mathrm{~h}$. Goat anti-rat HRPO conjugate in $1 \%$ BSA with $5 \%$ FBS and $5 \%$ NMS was then added. After incubation for $1 \mathrm{~h}$, the substrate (ABTS) was added.

Inhibition by anti-Id antibodies of reaction of $M A b$ AS-1 with ASV: Equal volumes of MAb AS-1 $(2.5 \mu \mathrm{g}$ $\mathrm{ml}^{-1}$ ) and 2-fold serial dilutions of adsorbed rat anti-Id serum (or NRS) in 3\% BSA were preincubated at room temperature for $2 \mathrm{~h}$. The mixtures were then added to wells of ELISA plates previously coated with purified ASV $\left(7 \times 10^{6}\right.$ TCID $_{50}$ per well $)$ and incubated at $37^{\circ} \mathrm{C}$ for $2 \mathrm{~h}$. After washing, peroxidase conjugate goat antimouse Ig in $1 \%$ BSA with $5 \%$ NRS was added for $1 \mathrm{~h}$ followed by addition of the substrate ABTS. The results were measured by $A_{405}$ and the percent of inhibition of binding of MAb AS-1 to ASV was determined by the following formula (Schick et al. 1987):

$$
\% \text { Inhibition }=100 \times\left(1-\frac{\mathrm{A}-\mathrm{C}}{\mathrm{B}-\mathrm{C}}\right)
$$

where $\mathrm{A}=A_{405}$ with competitor; $\mathrm{B}=A_{405}$ without competitor; $C=A_{405}$ of negative control.

Inhibition by ASV of binding of rat anti-Id antibodies to $\boldsymbol{M A b} \boldsymbol{A S}$-1: Alternatively, MAb AS-1 $\left(5 \mu \mathrm{g} \mathrm{m} \mathbf{l}^{-1}\right.$ in PBS) was coated to plates by incubation at room temperature for $1 \mathrm{~h}$. Two-fold serial dilutions of purified ASV $(100 \mu l)$ were added to the plates at $37^{\circ} \mathrm{C}$ for $1.5 \mathrm{~h}$ followed by adsorbed rat anti-Id sera at a 1:256 dilution for an additional $1 \mathrm{~h}$ incubation at $37^{\circ} \mathrm{C}$. Peroxidaseconjugated goat anti-rat Ig in 3\% BSA with $5 \%$ BCS (bovine calf serum) and 3\% NMS was added for $1 \mathrm{~h}$ followed by ABTS substrate. The results were measured as described previously.

Binding of anti-Id antibody to fish cell cultures. The method for immunoassay in cell cultures was a modification of the methods described by Guillet et al. (1985) and Vlaspolder et al. (1988). Three salmonid fish cell lines (CHSE-214, RTG-2 and AS) as well as 2 non-salmonid cell lines (BB and BF-2) were selected for direct binding assays with anti-Id antibodies. Cells were grown in 96-well microtiter plates until confluent monolayers were obtained. After fixation with $0.1 \%$ glutaraldehyde in PBS, cells were washed and endogenous peroxidase eliminated by adding 1 to 2 drops of $3 \%$ hydrogen peroxide for 1 to 2 min. After blocking with $1 \%$ BSA and $5 \%$ FBS, $50 \mu l$ of serial 2 -fold dilutions of purified rat anti-Id antibodies (or normal rat Ig) were added to the plate. After incubation for $1.5 \mathrm{~h}$, goat anti-rat HRPO in $1 \%$ BSA was added, followed by the substrate ABTS. The results were determined as described previously for ELISA assays.

BB cell cultures were used in blocking assays. Purified ASV $\left(2.3 \times 10^{11}\right.$ virus particles $\left.\mathrm{ml}^{-1}\right)$ was prepared in aliquots of $100,50,25$ and $10 \mu \mathrm{l}$ and added to glutaraldehyde fixed monolayers of BB cells in a 96-well tissue culture plate for $30 \mathrm{~min}$. A total of $50 \mu \mathrm{l}$ of purified rat anti-Id antibodies or normal rat Ig at a concentration of $10 \mu \mathrm{g} \mathrm{ml}^{-1}$ were directly added for another $1.5 \mathrm{~h}$ of incubation at room temperature. After incubation for $1.5 \mathrm{~h}$ with biotin labeled anti-Id, avidin-HRPO conjugate and substrate were added and the results determined as described previously

In addition, a modification of the method described. by Marriott et al. (1987) for protecting cells from viral infection by treatment with anti-Id antibodies was tested. Briefly, CHSE-214 cells were propagated in 96-well plates until confluence. Rat anti-Id antibodies or normal rat Ig prepared in medium (MEM) (80 and $40 \mu \mathrm{g} \mathrm{ml}^{-1}$ ) were added to the cells. After incubation for $1 \mathrm{~h}$ at $20^{\circ} \mathrm{C}, 50 \mu \mathrm{l}$ of unpurified ASV $\left(400 \mathrm{TCID}_{50}\right.$ $\mathrm{ml}^{-1}$ ) were added. Cells were incubated at $20^{\circ} \mathrm{C}$ for $88 \mathrm{~h}$, the supernatants harvested, and the TCID 50 virus titers determined by method of Reed \& Muench (1938).

\section{RESULTS}

\section{Production and initial characterization of anti-Id antibodies (anti-Id)}

\section{Reaction of rat anti-Id serum with MAb AS-1 and MAb AS- $1 \mathrm{~F}(\mathrm{ab})_{2}$ fragments}

Polyclonal anti-idiotype (anti-Id) antibodies were produced by immunizing rats with purified MAb AS-1 as described in the 'Materials and methods'. Antibodies reacting with normal mouse immunaglobulin were removed from the sera by adsorption on an affinity column coupled with normal mouse immunoglobulin. Anti-Ids were further purified by adsorption on and elution from a column coupled with the idiotype (Id) 

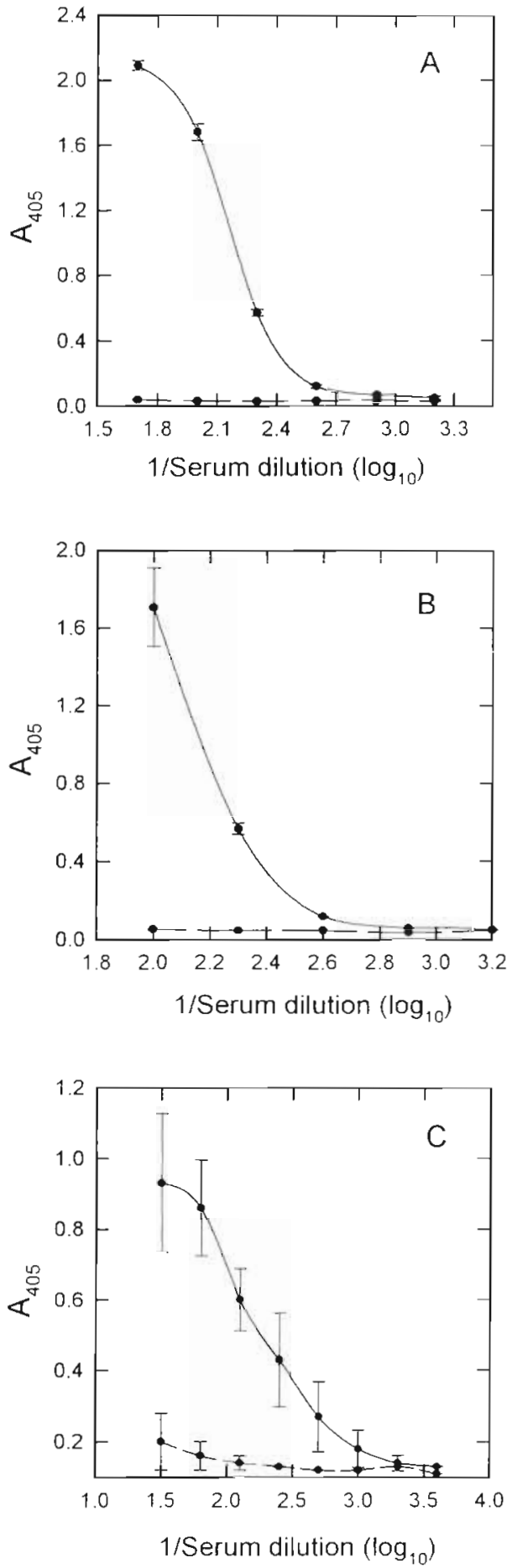

Fig. 1. (A) Reaction in ELISA of anti-Id serum with MAb AS-1. $A_{405}$ : mean $\pm \mathrm{SD}$ of 2 replicates. ( $(-)$ anti-Id antiserum; (- -) normal rat serum. (B) Reaction in ELISA of anti-Id serum with MAb AS-1 and MOPC-21, an unrelated myeloma protein of the same isotype. (-) MAb AS-1; (- -) MOPC. 21. (C) Reaction in ELISA of anti-Id antiserum with $\mathrm{F}(\mathrm{ab})_{2}$ fragments of Mab AS-1 and $\mathrm{F}(\mathrm{ab})_{2}$ fragments of an unrelated Ig of the same isotype. (-) MAb AS-1 F(ab) $)_{2}$ fragments; (- -) MAb G3-395 $\mathrm{F}(\mathrm{ab})_{2}$ fragments. (A to C) $A_{405}$ : mean $\pm \mathrm{SD}$ of 2 fragments antibody, MAb AS-1. Reactivity of the purified anti-Id antibody with MAb AS-1 was demonstrated in an ELISA (Fig. 1A). Significant binding of anti-Id to MAb AS-1 with a titer of at least 1:200 was demonstrated whereas no reaction was detected with NRS. Further evidence of the idiotypic specificity of the reaction was the failure of the anti-Id to react under similar conditions with MOPC-21, an unrelated mouse monoclonal idiotype of the same isotype (mouse $\operatorname{IgG}_{1}$ kappa) as MAb AS-1 (Fig. 1B). Additional evidence that the binding activity of the anti-Id was directed at the idiotypic region of MAb AS-1 was obtained by testing the ability to bind to $F(a b)_{2}$ fragments of MAb AS-1. As shown in Fig. $1 \mathrm{C}$, the reactivity of the anti-Id antibodies with MAb AS-1 F(ab) ${ }_{2}$ fragments was only slightly less than with whole immunoglobulin molecules. Again, essentially no reaction above background levels was detected with $\mathrm{F}(\mathrm{ab})_{2}$ fragments of another unrelated mouse $\mathrm{IgG}_{1}$ monoclonal idiotype (GS-395 IgG) but the same isotype.

\section{Confirmation of $\beta$-type anti-Id antibodies ( $\beta$-Ab2)}

Several blocking assays were used to determine if these anti-Id antibodies were directed against the paratope of MAb AS-1 and that they were, indeed, a reverse image of the paratope and molecularly mimicked the ASV virion epitope.

\section{Inhibition by rat anti-Id antibodies of binding of MAb AS-1 to ASV}

Preincubation of anti-Id antibody with MAb AS-1 resulted in a significant inhibition of the subsequent reaction in an ELISA of MAb AS-1 with ASV (Fig. 2A). Furthermore, reaction of purified ASV with MAb AS-1 significantly (>60\%) blocked binding of MAb AS-1 to anti-Id (Fig. 2B). These results suggested that the population of anti-Id antibodies included antibodies recognizing paratope-associated idiotopes.

Inhibition by anti-Id antibodies of virus neutralization by MAb AS-1

Further evidence that the anti-Id antibodies mimicked the virion epitope recognized by MAb AS-1 was obtained by demonstration that the anti-Id antibodies could functionally block the ability of MAb AS-1 to neutralize viral infectivity in plaque-inhibition assays (Table 1). Reaction of ASV with a standard preparation of MAb AS-1 resulted in a $>90 \%$ reduction in plaque numbers. A similar level of neutralization was ob- 

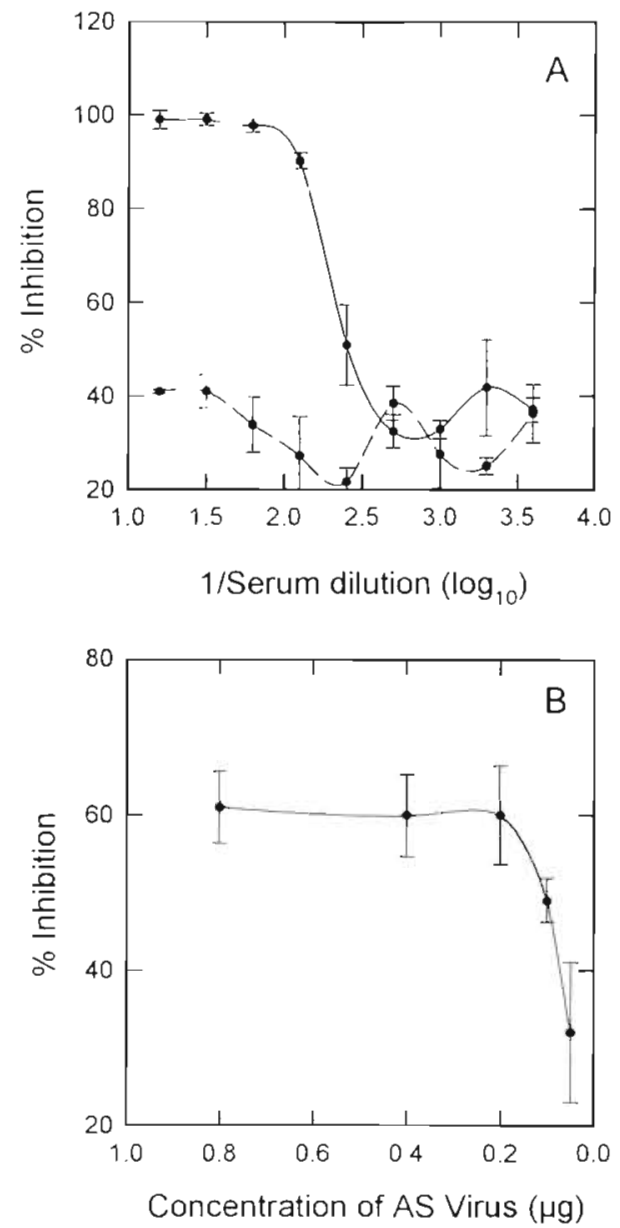

Fig. 2. (A) Inhibition of binding of MAb AS-1 to ASV by rat anti-Id antibodies. \% Inhibition: mean \pm SD of 2 replicates. (-) anti-Id antibodies; (- -) normal rat serum. (B) Inhibition by ASV of anti-Id antibody binding to MAb AS-1

$\%$ Inhibition: mean \pm SD of 3 replicates

Table 1. Ability of anti-idiotype (anti-Id) antibodies to block neutralization of Atlantic salmon virus (ASV) by the monoclonal antibody MAb AS-1 in plaque reduction assays. NRS: normal rat serum; MEM: minimum essential medium

\begin{tabular}{|c|c|c|c|c|}
\hline \multirow{2}{*}{$\begin{array}{l}\text { Anti-Id } \\
\text { dilution }\end{array}$} & \multicolumn{4}{|c|}{ Number of plaques $\pm \mathrm{SD}^{\mathrm{a}}$} \\
\hline & $\begin{array}{c}\text { ASV } \\
++ \\
\text { MAb AS-1 } \\
+ \\
\text { Anti-Id }\end{array}$ & $\begin{array}{c}\text { ASV } \\
++ \\
\mathrm{MAb}^{+} \mathrm{AS}-1 \\
+ \\
\text { NRS }\end{array}$ & $\begin{array}{c}\text { ASV } \\
\stackrel{+}{ } \\
\text { MEM } \\
\stackrel{+}{\text { MEM }}\end{array}$ & $\begin{array}{c}\text { ASV } \\
{ }^{+} \\
\mathrm{MAb}^{+} \mathrm{AS}-1 \\
\stackrel{+}{E}^{-1}\end{array}$ \\
\hline $1: 32$ & $>100^{b}$ & $2.0 \pm 1.4$ & & \\
\hline $1: 64$ & $>100^{b}$ & $1.5 \pm 2.1$ & & \\
\hline $1: 128$ & $2.5 \pm 0.7$ & $0.5 \pm 0.7$ & & \\
\hline $1: 256$ & $2.5 \pm 0.7$ & $3.0 \pm 1.4$ & & \\
\hline $1: 512$ & $2.0 \pm 1.4$ & $3.5 \pm 3.5$ & & \\
\hline $1: 1024$ & $2.0 \pm 2.8$ & $2.0 \pm 2.8$ & & \\
\hline No anti-Id & & & $>100^{\circ}$ & \\
\hline No anti-Id & & & & $7.0 \pm 2.6$ \\
\hline
\end{tabular}

served when MAb AS-1 was preincubated with NRS. However, preincubation of MAb AS-1 with anti-Id antibody at dilutions of 1:32 and 1:64 resulted in no detectable virus neutralization. Inhibition of virus neutralization by MAb AS-1 was eliminated with higher dilutions of anti-Id antibodies.

Induction of neutralizing anti-viral antibodies (anti-anti-Id antibodies) (Ab3) in mice by immunization with anti-Id antibodies

The results described previously demonstrated that the rat anti-Id antibodies included $\beta$-type anti-Id antibodies that molecularly mimicked the virion epitope identified by MAb AS- 1 and competed with virus in various serological assays. Therefore, it was of interest to determine whether these anti-Id antibodies could be used as surrogate antigens to generate production of anti-virus antibodies in laboratory animals. $B A L B / C$ mice were immunized with purified rat antiId antibodies as described in the 'Materials and methods'. Anti-anti-Id sera (Ab3) from 4 mice were tested for the ability to neutralize ASV in cell culture. The $50 \%$ neutralization titer $\left(\mathrm{ND}_{50}\right)$ of each antiserum was determined (Table 2). All 4 Ab3 sera exhibited virus neutralizing activity, ranging in $\mathrm{ND}_{50}$ titers from 40 to 316 .

Anti-Id antibody as an anti-receptor antibody

Since MAb AS-1 is a virus neutralizing antibody, it was of interest to determine if the virion epitope recognized by this MAb is a cell attachment site that recognizes and binds to a complementary receptor on the surface of susceptible cells. Therefore, the anti-Id antibodies mimicking the virion epitope were tested for ability to bind to various cell cultures of both salmonid and non-salmonid origin and to compete with virus in binding to cells.

Table 2. Neutralization of Atlantic salmon virus by mouse anti-anti-idiotype antibodies ( $\mathrm{Ab} 3$ ). $\mathrm{ND}_{50}: 50 \%$ neutralization end point. Reciprocal of dilution of mouse antiserum protecting $50 \%$ of cell cultures infected with virus at a concentration of $400 \mathrm{TCID}_{50} \mathrm{ml}^{-1}$; NMS: normal mouse serum

\begin{tabular}{|cc|}
\hline Mouse serum & ND 50 \\
\hline BM5 & 97 \\
BM6 & 316 \\
BM8 & 40 \\
BM9 & 53 \\
NMS & $<8$ \\
\hline
\end{tabular}


Direct cell binding assay

In order to determine if the rat anti-Id antibodies could bind to these fish cells, direct binding tests were performed by a modified ELISA using glutaraldehyde fixed cell monolayers as described in the 'Materials and methods'. The results with CHSE- 214 cells are shown in Fig. 3A. Some non-specific binding of normal rat Ig to CHSE-214 cells was observed. However, significantly higher levels of binding of anti-Id antibodies to these cells was observed in comparison with normal rat Ig. Similar results were also obtained with 2 other salmonid cell lines, AS cells (Fig. 3B) and RTG-2 cells (Fig. 3C). The basis for the relatively high levels of binding of normal rat Ig to fish cells is unknown. Similar levels of binding of normal rat Ig were observed with 2 non-salmonid fish cell lines (BF-2 and BB cells). Again, however, significantly higher levels of binding to both BF-2 and BB cells were demonstrated with anti-Id antibodies (Fig. 3D, E).

Competition of anti-Id antibodies with ASV in binding to fish cell cultures

In order to determine if the anti-Id antibodies were binding specifically to cellular receptors for the virus,
$\mathrm{BB}$ cell lines were treated with ASV and tested for inhibition of subsequent binding of anti-Id. As shown in Table 3, treatment of BB cells with ASV (100 $\mu$ l per well) resulted in a significant inhibition ( $52 \%$ ) of subsequent binding of anti-Id antibodies. Treatment of cells with ASV resulted in little or no inhibition of the previously described non-specific binding of normal rat Ig to these cells. These results suggest that both virus and anti-Id antibodies recognize and bind to the same site on the surface of these cells.

Effect of treatment of cells with anti-Id antibodies on replication of $\mathrm{ASV}$

The effect of treatment of fish cell cultures with antiId antibodies on the replication of ASV was also investigated. CHSE-214 cells were first treated with either rat anti-Id antibodies, normal rat Ig, or MEM cell culture medium for $1 \mathrm{~h}$, after which they were infected with virus $\left(400 \mathrm{TClD}_{50} \mathrm{ml}^{-1}\right)$. After incubation for $88 \mathrm{~h}$, the culture supernatants were harvested and the virus titers determined. The results are shown in Table 4. The final virus titers in those cell cultures treated with normal rat Ig or MEM culture medium were identical. In contrast, the virus titers in cells treated with 80 and
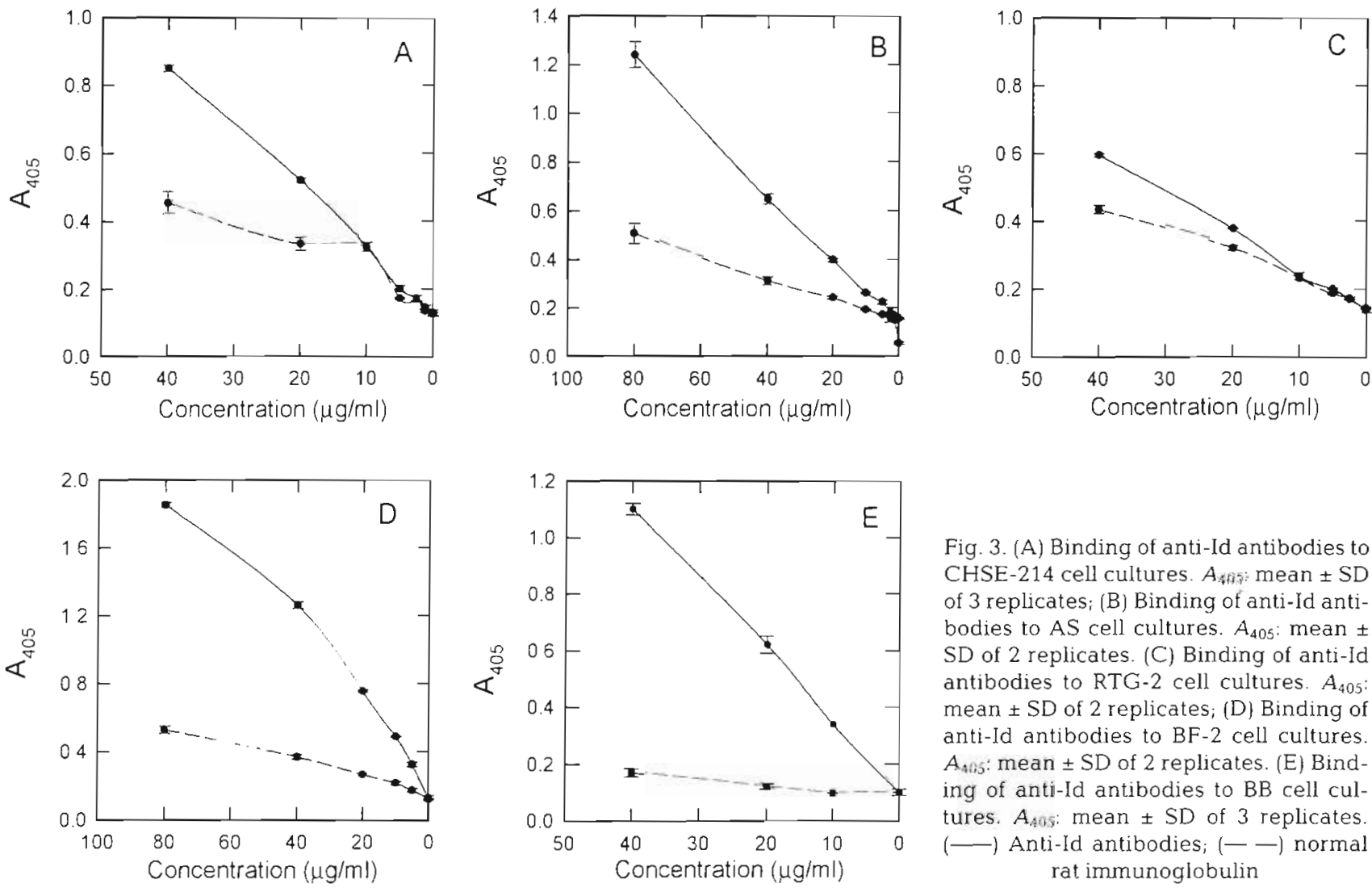

Fig. 3. (A) Binding of anti-Id antibodies to CHSE-214 cell cultures. $A_{405}$ : mean \pm SD of 3 replicates; (B) Binding of anti-Id antibodies to AS cell cultures. $A_{405}$ : mean \pm $\mathrm{SD}$ of 2 replicates. (C) Binding of anti-Id antibodies to RTG-2 cell cultures. $A_{405}$ : mean \pm SD of 2 replicates; (D) Binding of anti-Id antibodies to $\mathrm{BF}-2$ cell cultures. $A_{405}$ : mean $\pm \mathrm{SD}$ of 2 replicates. (E) Binding of anti-Id antibodies to BB cell cultures. $A_{405}$ : mean $\pm \mathrm{SD}$ of 3 replicates. (-) Anli-Id antibodies; (- -) normal rat immunoglobulin 
Table 3. Inhibition by Atlantic salmon virus (ASV) of binding of antiidiotype (anti-Id) antibodies to brown bull head cell cultures

\begin{tabular}{|c|c|c|c|c|}
\hline \multirow{3}{*}{$\begin{array}{c}\text { ASV }^{\circ} \\
\left(\mu l \text { well } l^{-1}\right)\end{array}$} & \multicolumn{4}{|c|}{ Inhibitor } \\
\hline & \multicolumn{2}{|c|}{ Anti-Id ${ }^{b}$} & \multicolumn{2}{|c|}{ Normal rat $\operatorname{Ig}^{b}$} \\
\hline & $A_{405} \pm S D^{C}$ & $\%$ Inhibition & $A_{405} \pm \mathrm{SD}^{c}$ & $\%$ Inhibition \\
\hline 100 & $0.068 \pm 0.03$ & 52.4 & $0.07 \pm 0.01$ & 0 \\
\hline 50 & $0.103 \pm 0.01$ & 28.0 & $0.059 \pm 0.01$ & 4.8 \\
\hline 25 & $0.166 \pm 0.00$ & 0 & $0.075 \pm 0.03$ & 0 \\
\hline 10 & $0.163 \pm 0.02$ & 0 & $0.076 \pm 0.02$ & 0 \\
\hline No ASV & $0.143 \pm 0.02$ & - & $0.062 \pm 0.02$ & - \\
\hline \multicolumn{5}{|c|}{$\begin{array}{l}\text { d } 2.3 \times 10^{11} \text { viral particles } \mathrm{ml}^{-1} \\
\mathrm{~b} 10 \mathrm{\mu g} \mathrm{ml^{-1 }} \text { of anti-Id or normal rat Ig were used } \\
\text { "Mean } \pm \mathrm{SD} \text { of } 2 \text { replicates; absorbance is shown after subtracting } \\
\text { values from the negative control }\end{array}$} \\
\hline
\end{tabular}

Table 4. Effect of treatment of CHSE-214 cell cultures with anti-idiotype (anti-Id) antibodies on the yield of progeny virus. TCID ${ }_{50}$ : tissue culture infectious dose-50\%; NR Ig: normal rat serum; MEM: minimum essential medium; ND: not done

\begin{tabular}{|c|c|c|c|c|}
\hline Treatment & $\begin{array}{l}\text { Virus titer (lc } \\
\text { Anti-Id }\end{array}$ & $\begin{array}{l}\mathrm{TCID}_{50} \mathrm{r} \\
\mathrm{NR} \text { Ig }\end{array}$ & $\begin{array}{l}\text { in presence of } \\
\text { MEM }\end{array}$ & $\begin{array}{l}\% \text { Anti-Id } \\
\text { inhibition }\end{array}$ \\
\hline $80 \mu \mathrm{g} \mathrm{ml}^{-1}$ & 5.5 & 7.0 & 7.2 & 98.1 \\
\hline $40 \mu \mathrm{g} \mathrm{ml}^{-1}$ & 6.1 & 7.1 & ND & 92.9 \\
\hline \multicolumn{5}{|c|}{$\begin{array}{l}{ }^{0} \mathrm{TCID}_{50} \mathrm{ml}^{-1} \text { was calculated on Day } 6 \text { after infection; } \\
\text { mean of } 2 \text { replicates }\end{array}$} \\
\hline
\end{tabular}

$40 \mu \mathrm{g} \mathrm{ml} \mathrm{m}^{-1}$ of rat anti-Id antibodies were 98 and $93 \%$ lower, respectively, than titers from either control culture.

\section{DISCUSSION}

The general goal of this investigation was to explore the potential of anti-Id antibodies that molecularly mimic specific epitopes on aquatic birnaviruses for use as surrogate viral antigens and research probes for investigating the function of virion epitopes. The approach used was to develop anti-Id antibodies against a neutralizing monoclonal antibody (MAb AS-1) that, in previous studies (Lipipun 1988, Caswell-Reno et al. 1989, Lipipun et al. 1989), had been shown to recognize a virion epitope that is highly conserved among aquatic birnaviruses and, thus, may play a critical role in the structure and/or function of these viruses.

The production of anti-Id antibodies was demonstrated in several assays. In ELISA assays, high levels of binding of the anti-Id antibodies were demonstrated with MAb AS-1 whereas no binding was observed with MOPC-21, an unrelated mouse myeloma protein of the same isotype as MAb AS-1 (IgG1, kappa)
(Fig. 1B). Moreover, anti-Id antibodies exhibited a strong, dose-dependent reaction with $\mathrm{F}(\mathrm{ab})_{2}$ fragments of MAb AS-1 and did not react with control $\mathrm{F}(\mathrm{ab})_{2}$ fragments (Fig. $1 \mathrm{C}$ ). These results indicated that the rat anti-MAb AS-1 serum contained antibodies specific for MAb AS-1 idiotopes (i.e. anti-ld antibodies). However, as discussed previously, only $\beta$-type anti-Id antibodies are directed against the paratope of the idiotype antibody and, hence, molecularly mimic the 3 -dimensional structure of the original antigen epitope. Several approaches were used to demonstrate that the rat anti-MAb AS- 1 serum contained $\beta$-type anti-Id antibodies. First, anti-Id antibodies were tested for ability to block the binding of the idiotype antibody (MAb AS-1) to virus. As shown in Fig. 2A, anti-Id antibodies inhibited the reaction in an ELISA of MAb AS- 1 with ASV in a dose dependent manner with $100 \%$ inhibition at higher concentrations. Some non-specific inhibition was observed with NRS, but the level of inhibition was significantly lower than that observed with anti-Id preparations and equivalent to that obtained with higher dilutions of anti-Id antibodies where, presumably, anti-Id activity had been diluted out. Similar non-specific inhibitions by normal animal sera or control immunoglobulins at levels of 10 to $30 \%$ have been reported with comparable assays in other studies of anti-Id antibodies (Lathey et al. 1987, Srikumaran et al. 1990, Lamarre et al. 1991). Anti-Id antibodies also were shown to functionally interfere with MAb AS-1. Reaction of anti-Id antibodies at dilutions up to 1:64 effectively abolished the ability of MAb AS-1 to neutralize virus infectivity in plaque reduction assays (Table 1). Thus, binding of anti-Id antibodies to MAb AS-1 resulted in an inhibition of both the ability of MAb AS-1 to bind to virus and to neutralize virus infectivity, suggesting that the anti-Id antibodies were binding specifically to the paratope region of the idiotype antibody. If this was the case, reaction of virus with MAb AS- 1 should also have resulted in an inhibition of the subsequent binding of anti-Id antibodies to MAb AS-1. As shown in Fig. 2B, incubation with ASV resulted in approximately a $60 \%$ inhibition of the subsequent reaction of MAb AS-1 with anti-Id antibodies. There are several possible explanations for the fact that ASV was not able to completely block the reaction of MAb AS-1 with anti-Id antibodies. Although relatively high concentrations of virus were used, the amounts of virus may still have been insufficient to saturate all of the binding sites on MAb AS-1 immunoglobulin molecules. However, this seems unlikely since identical levels of inhibition were 
obtained with 3 different concentrations of virus $(0.8$, 0.4 , and $0.2 \mu \mathrm{g}$ ). A more likely explanation, however, relates to the fact that the anti-Id antibodies used were polyclonal. Polyclonal anti-Id antibodies would contain populations of all categories of anti-Id antibodies including not only $\beta$-type anti-Id antibodies directed against the MAb AS-1 paratope but also antibodies directed against non-paratope regions. Reaction of nonparatope specific antibodies would not be specifically blocked by virus bound to the paratope region except by possible non-specific stearic hindrance. Hence, inhibition levels of $60 \%$ in these assays actually seem relatively high, which might suggest that a relatively large percentage of the anti-Id antibodies in the preparation were of the $\beta$-type. The evidence discussed above strongly indicated that the anti-Id antibodies were directed against the $F(a b)_{2}$ region of the idiotype antibody and that the serum contained significant levels of $\beta$-type anti-Id antibodies which were directed against the paratope region and which molecularly mimicked the ASV epitope.

Anti-Id antibodies (Ab2) of the $\beta$-type have been used as surrogate antigens to induce an immune response eliciting the production of anti-anti-Id antibodies (Ab3) which function like the idiotype antibody (Ab1) and recognize the original antigen epitope. AntiId antibodies have been used to stimulate an immune response against a variety of pathogens (Reagan et al. 1982, Sacks et al. 1982, McNamara et al. 1984, Sharpe et al. 1984, Stein \& Soderstrom 1984, Gell et al. 1985 , Grzych et al. 1985, Kaufmann et al. 1985, Kennedy et al. 1986, Bhogal et al. 1988). Therefore, one of the goals of this investigation was to determine if these anti-Id antibodies could be used as surrogate antigens to elicit a specific immune response against aquatic birnaviruses. Purified rat anti-Id antibody mixed with complete Freund's adjuvant was injected i.p. into BALB/c mice as described in the 'Materials and methods'. As shown in Table 2, Ab3 antisera from all 4 mice tested exhibited virus-neutralizing activity with titers ranging from $1: 40$ to $1: 316$. Studies using rabbits or some other larger animal, other than rats, could be used to produce larger quantities of such anti-Id antibodies and investigate the ability of anti-Id antibodies to elicit a similar immune response in fish. Also, the development of monoclonal anti-Id antibodies would be ideal for generating unlimited amounts of homogeneous anti-Id populations

The use of anti-Id antibodies as surrogate antigens in vaccines has been suggested for a number of viruses and other pathogens, particularly in cases where the pathogen is extremely dangerous, difficult or expensive to produce, and/or when preparation of the vaccine might result in the denaturation of critical conformationally dependent epitopes (i.e. subunit viral vac- cines). Theoretically, anti-Id antibodies such as those produced in this investigation could have the potential for use in vaccines against aquatic birnaviruses and other fish viruses. The practicality of such vaccines, however, will depend on the ability to generate monoclonal anti-Id antibodies which can be produced more economically and on the success of more typical approaches to vaccine development such as recombinant DNA expressed viral subunit vaccines.

Virtually nothing is known about the cell receptors for aquatic birnaviruses or the interaction of these viruses with cell surface components that mediate possible cell tropisms, species specificity, and the production of different diseases in different fish species. Therefore, another goal of this investigation was to use these anti-Id antibodies to investigate the role of this epitope as a virion attachment site that recognizes and binds to fish cell receptors. This approach has been used to identify and characterize cellular receptors for other viruses including: Sindbis virus (Wang et al. 1991), polyoma virus (Marriott et al. 1987), alphavirus (Ubol \& Griffin 1991), bovine herpesvirus (Srikumaran et al. 1990, Hariharan et al. 1991), and reovirus (Co et al. 1985).

A modified ELISA using glutaraldehyde fixed cell monolayers was used in direct binding assays to determine whether the rat anti-Id antibodies could bind to cells of various fish cell cultures. Experimental controls with normal rat immunoglobulin indicated some nonspecific binding of rat immunoglobulin to cells of all 5 fish cell lines. It is possible that the surface of these cells contain lectins that bind the immunoglobulin $F_{C}$ region carbohydrate. Indeed, carbohydrate-binding lectins have been isolated from eggs of several fish species (Krajhanze et al. 1978). The presence of such lectins on the surface of the fish cell cultures could explain the observed non-specific binding of rat immunoglobulin. Nevertheless, levels of binding significantly above those observed with normal rat immunoglobulin were demonstrated with anti-Id antibodies in all 5 fish cell cultures (Fig. 3). Although confluent monolayers in 96-well microtiter plates were used for all 5 cell lines, no attempt was made to ensure that exactly the same number of cells were present in each case. Therefore, observed differences in levels of anti-Id binding could be the result of variations in the numbers of cells in different cell cultures. In any event, these data demonstrate that the anti-Id antibodies mimicking the AS- 1 epitope bind to fish cells in culture at levels significantly greater than normal rat Ig and suggest, therefore, that this epitope could represent a cell attachment site on the virion.

As shown in Table 3 incubation of BB cells with 100 and $50 \mu \mathrm{l}$ of ASV $\left(2.3 \times 10^{11}\right.$ and $1.1 \times 10^{10}$ viral particles $\mathrm{ml}^{-1}$ ) resulted in a 52 and $28 \%$ inhibition, respec- 
tively, in the binding of anti-Id antibodies. Furthermore, ASV did not result in any appreciable inhibition of the non-specific reaction of normal rat iramunoglobulin typically observed with these cells. Since cells typically have large numbers of virus receptors (e.g 50000 to 78000 receptors per cell for reovirus type 3) (Co et al. 1985), it is unlikely that all receptors could be saturated with the quantities of virus used and, therefore, higher levels of inhibition may be observed with higher concentrations of virus.

The demonstration of direct binding of anti-Id antibodies to a variety of fish cell cultures and the ability of virus to block binding of anti-ld antibodies suggest that the AS-1 epitope may be a cell attachment site on the virus which recognizes an aquatic birnavirus cellular receptor. The fact that complete blocking of anti-Id antibody binding by virus was not observed is likely the result of one or more of the factors discussed above. However, the levels of inhibition obtained were comparable to inhibition levels reported by other investigators in similar studies with anti-Id antibodies (Marriott et al. 1987, Wang et al. 1991).

Since anti-Id antibodies had been demonstrated to bind to fish cell cultures, presumably to virus receptors, and virus binding partially blocked subsequent binding to fish cells of anti-Id antibodies, it was reasoned that treatment of fish cells cultures with anti-Id antibodies should result in a decreased yield of virus in such cultures. The yields of virus in cells treated either with MEM or normal rat immunoglobulin were virtually identical $\left(1.0\right.$ to $\left.1.63 \times 10^{7} \mathrm{TCID}_{50} \mathrm{ml}^{-1}\right)$ (Table 4 ). However, the yield of virus in cells treated with anti-Id antibodies was $3.16 \times 10^{5} \mathrm{TCID}_{50} \mathrm{ml}^{-1}$. Therefore, treatment of cells with anti-Id antibodies resulted in an inhibition of approximately $98 \%$ in the yield of virus in these cells.

These data indicate that these anti-Id antibodies are binding to an aquatic birnavirus receptor on the surface of fish cells and that the AS-1 virion epitope is a cell attachment site that recognizes and binds to this receptor. Such anti-Id antibodies, therefore, could be useful in further studies to investigate the nature of this receptor and its interactions with virus. For example, anti-Id antibodies could be used in conjunction with flow cytometry and/or immunofluorescent assays to determine the following: whether all cells in a population possess a specific receptor; the relative number and distribution of a receptor on the surface of various cells; the presence of a receptor on the surface of cells of different fish species, tissues, or organs; and the expression of a receptor on various cells at different stages of fish development. Additionally, they could be used as probes in western blots of SDS-PAGE separated proteins from cell membrane extracts or immunoprecipitation from membrane extracts to isolate and characterize a receptor. Such studies could pro- vide valuable information about the ability of these viruses to adapt to new hosts and about possible cell or tissue tropisms that may mediate different diseases observed in different host species.

In summary, this investigation has demonstrated that anti-Id antibodies can be produced that molecularly mimic the conformation of individual antigenic epitopes on aquatic birnaviruses and that these anti-Id antibodies can serve as surrogate antigens in stimulating the production of neutralizing anti-virus antibodies. More specifically, these results demonstrate that anti-Id antibodies mimicking the 3-dimensional structure of the AS-1 epitope on aquatic birnaviruses can induce the production of neutralizing antibodies, suggesting that this epitope is important in stimulating a protective immune response to these viruses. Also, demonstration that these anti-Id antibodies bind to a variety of fish cell cultures and block virus replication indicate that the virion epitope recognized by MAb AS- 1 is a cell attachment site that recognizes cell receptors.

Acknowledgements. This work was supported by grants from NOAA Sea Grant (R/FMD-217 and R/FMD-235), the National Science Foundation (NSF INT-8504094), the Maine Agricultural and Forest Experiment Station, and the University of Maine Center for Marine Studies. This is Maine Agricultural and Forest Experiment Station Publication 2056.

\section{LITERATURE CITED}

Anders EM, Kapaklis Deliyannis GP, White DO (1989) Induction of immune response to influenza virus with antiidiotypic antibodies. J Virol 63:2758-2767

Anderson PS (1986) The production of monoclonal antibodies to the menhaden isolate of infectious pancreatic necrosis virus. MSc thesis. University of Maine, Orono

Ardman B, Khiroya RH, Schwarta RS (1985) Recognition of a leukemia-related antigen by an anti-idiotypic antiserum to an anti-gp70 monoclonal antibody. J Exper Med 161: 669-686

Bhogal BS, Nollstadt KH, Karkhanis YD, Schmatz DM, Jacobson EB (1988) Anti-idiotypic antibody with potential use as an Eimeria tenellasporozoite antigen surrogate for vaccination of chickens against coccidiosis. Infect Immun 56: 1113-1119

Caswell-Reno P, Lipipun V, Reno PW, Nicholson BL (1989) Use of a group-reactive and other monoclonal antibodies in an enzyme immunodot assay for identification and presumptive serotyping of aquatic birnaviruses. J Clin Microbiol 27:1924-1929

Caswell-Reno P, Reno PW, Nicholson BL (1986) Monoclonal antibodies to infectious necrosis virus: analysis of viral epitopes and comparison of different isolates. J Gen Virol $67: 2193-2205$

Cerini CP, Malsberger RG (1962) Fish cell and tissue culture. In: Hoar WS, Randall DJ (eds) Fish physiology, Vol. 3. Academic Press, New York, p 253-301

Co MS, Gaulton GN, Fields BN, Green MI (1985) Isolation and biochemical characterization of the mammalian reovirus type 3 cell surface receptor. Proc Natl Acad Sci USA 82:1494-1498 
Dobos P, Hill BJ, Hallett R, Kells DTC, Becht H, Teninges D (1979) Biophysical and biochemical characterization of five animal viruses with bisegmented double stranded RNA genomes. J Virol 32:593-605

Farid NR, Linthicum DS (1988) Idiotype, paratope, and molecular mimicry. In: Linthicum DS, Farid NR (eds) Antiidiotypes, receptors, and molecular mimicry. SpringerVerlag, New York, p 1-5

Fuller AO, Santos RE, Spear PG (1989) Neutralizing antibodies specific for glycoprotein $\mathrm{H}$ of Herpes simplex virus permit viral attachment to cells but prevent penetration. J Virol 63:3435-3443

Gaulton GN, Co MS, Royer HD, Greene MI (1985) Antiidiotypic antibodies as probes of cell receptors. Molec Cell Biochem 65:5-21

Gell PGH, Moss PAH (1985) Production of cell-mediated immune response to herpes simplex virus by immunization with anti-idiotype heteroantisera. J Gen Virol 66:1801-1804

Grzych JM, Capron M, Lambert PH, Dissous C, Torres S, Capron A (1985) An anti-idiotype vaccine against experimental schistosomiasis. Nature 316:74-76

Guillet G, Kaveri SV, Durieu O, Delavier C, Hoebeke J, Strosberg D (1985) B-adrenergic against activity of a monoclonal anti-idiotypic antibody. Proc Natl Acad Sci USA 82:1781-1784

Hariharan K, Hariharan MJ, Zamb TJ, Krueger RJ, Srikumaran S (1991) Bovine monoclonal anti-idiotypes induce antibodies specific for a synthetic peptide bearing a neutralizing epitope of bovine herpesvirus 1 glycoprotein $\mathrm{gI}$ (gB). J Immunol 146:3489-3495

Hill BJ, Way K (1983) Serological classification of fish and shellfish birnaviruses. First Internatl Conf Eur Assoc Fish Pathol, Plymouth, England (abstract)

Johnstone A, Thorpe R (eds) (1982) Basic techniques. In: Immunochemistry in practice. London

Kauffman RS, Noseworthy JH, Nepom JT, Finberg R, Fields BN, Greene MI (1982) Cell receptors for the mammalian reovirus; II: monoclonal anti-idiotypic antibody blocks viral binding to cells. J Immunol 131:2539

Kaufmann SHE, Eichmann K, Muller I, Wrazel LJ (1985) Vaccination against the bacterium Listeria monocytogenes with a clonotypic antiserum. J Immunol 134:4123-4127

Keay S, Rasmussen L, Merigan TC (1988) Syngenic monoclonal anti-idiotype antibodies that bear the internal image of a human cytomegalovirus neutralization epitope. J Immunol 140:944-948

Kennedy RC, Eichberg JW, Lanford RE, Dreesman GR (1986) Anti-idiotype antibody vaccine for type $B$ virus hepatitis in chimpanzees. Science 232:220-223

Krajhanze A, Horejsi V, Kocoure JK (1978) Studies of lectins. XLI: Isolation and characterization of a blood group B specific lectin from the roe of the powan (Coregonus lavaretus maraena). Biochem Biophys Acta 523:209-214

Lamarre A, Lecomte J, Talbot PJ (1991) Antiidiotypic vaccination against murine corona virus infection. J Immunol $147: 4256-4262$

Lannan CN, Winton JR, Fryer JL (1984) Fish cell lines: establishment and characterization of nine cell lines from salmonids. In Vitro 20:671-676

Lathey JL, Courtney RJ, Rouse BT (1987) Production, binding characteristics, and immunogenicity of heterologous anti idiotypic antibody to herpes simplex virus glycoprotein $\mathrm{C}$. Viral Imnunol 1:13-23

Lipipun V (1988) Antigenic characterization and identification of aquatic birnaviruses using monoclonal antibodies $\mathrm{PhD}$ dissertation. University of Maine, Orono

Lipipun V, Caswell-Reno P, Hsu YL, Wu JL, Tung MT, Reno
PW, Wattanavijarn W, Nicholson BL (1989) Antigenic analysis of Asian aquatic birnavirus isolates using monoclonal antibodies. Fish Pathol 24:155-160

Lipipun V, Caswell-Reno P, Reno P, Nicholson BL (1992) Neutralization epitopes of aquatic birnaviruses are located on the VP2 protein. In: Fryer J (ed) Viruses of lower vertebrates. Proc Second Internl Symp Viruses Lower Vertebrates, Oregon State University, Corvallis, Oregon, p 269-277

Manning DS, Leong JC (1990) Expression in Escherichia coli of the large genomic segment of infectious pancreatic necrosis virus. Virology 179:16-25

Marriott SJ, Roeder DJ, Consigli RA (1987) Anti-idiotypic antibodies to a polyoma virus monoclonal antibody recognize cell surface components of mouse kidney cells and prevent polyoma virus infection. J Virol 61:2747-2753

McNamara MK, Ward RE, Kohler H (1984) Monoclonal idiotope vaccine against Streptococcus pneumoniae infection. Science 226:1325-1326

Nicholson BL, Byrne C (1973) An established cell line from the Atlantic salmon (Salmo salar). J Fish Res Bd Can 30 913-916

Nicholson BL, Thorne GW, Janicki C, Hanson A (1979) Studies on a host range variant from different isolates of infectious pancreatic necrosis virus (IPNV). J Fish Dis 2:367-379

Nicholson BL (1993) Use of monoclonal antibodies in fish disease research. In: Hetrick F, Faisal M (eds) Ann Rev Fish Dis, Pergamon Press, USA, p 241-257

Palomo C, Albar JP, Garcia-Barreno B, Melero JA (1990) Induction of a neutralizing immune response to human respiratory syncytial virus with anti-idiotypic antibodies. J Virol 64:4199-4206

Paque RE, Miller R (1989) Polyclonal anti-idiotypes influence macrophage chemotaxis in Coxsackie virus-induced murine myocarditis. J Leukocyte Biol 45:79-86

Paque RE, Miller R (1991) Auto anti-idiotypes exhibit mimicry of myocyte antigens in virus-induced myocarditis. J Virol $65: 16-22$

Reagan KJ, Wunner WH, Wiktor TJ, Koprowski H (1983) Anti-idiotypic antibodies induce neutralizing antibodies to rabies virus glyco-protein. J Virol 48:660-666

Reed LJ, Muench $\mathrm{H}$ (1938) A simple method of estimating fifty percent end points. Am J Hyg 27:493-497

Sacks DL, Esser KM, Sher A (1982) Immunization of mice against African trypanosomiasis using anti-idiotypic antibodies. J Exp Med 155:1108-1119

Scherrer R, Cohen J (1975) Studies on infectious pancreatic necrosis virus interactions with RTG-2 and FHM cells: selection of a variant virus-type in FHM cells. J Gen Virol 28:9-20

Schick MR, Dreesman GR, Kennedy RC (1987) Induction of an anti-hepatitis $B$ surface antigen response in mice by noninternal image (Ab2-alpha) anti-idiotypic antibodies $\mathrm{J}$ Immunol 138:3419-3425

Sharpe AH, Gaulton GN, McDade KK, Fields BN, Greene MI (1984) Syngenic monoclonal antiidiotype can induce cellular immunity to reovirus. J Exp Med 160:95-120

Smith RE, Zweerink HJ, Joklik WK (1969) Polypeptide components of virions, top component and cores of reovirus type 3. Virology 39:791

Srikumaran S, Onisk DV, Borca MV, Nataraj C, Zamb IJ (1990) Anti-idiotype antibodies induce neutralizing antibodies to bovine herpesvirus 1. Immunol 70:284-289

Stein KE, Soderstrom T (1984) Neonatal administration of idiotype or antiidiotype primes for protection against Escherichia coli K13 infection in mice. J Exp Med 160:1001-1011

Ubol S, Griffin DE (1991) Identification of a putative alpha- 
virus receptor on mouse neural cells. J Virol 65:6913-6912 Uytdehaag FGCM, Osterhaus ADME (1985) Induction of neutralizing antibody in mice against poliovirus type II with monoclonal anti-idiotypic antibody. J Immunol 134 $1225-1229$

Vlaspolder F, Harmsen T, van Veenendaal D, Kraaijeveld CA Snippe H (1988) Application of immunoassay of encephalomyocarditis virus in cell culture with enzyme-labeled virus-specific monoclonal antibodies for rapid detection of virus, neutralizing antibodies, and interferon. J Clin Microbiol 26:2593-2597

Responsible Subject Editor: F. M. Hetrick, College Park, Maryland, USA
Wang KS, Schmaliohn AL, Kuhn RJ, Strauss JH (1991) Antiidiotypic antibodies as probes for the Sindbis virus receptor. Virology 181:694-702

Wolf K (ed) (1988) Infectious pancreatic necrosis. In: Fish viruses and fish viral diseases. Cornell University Press Ithaca, New York, p 115-157

Wolf K, Quimby MC (1962) Established eurythermic line of fish cells in vitro. Science 135:1065-1066

Wolf K, Quimby MC (1966) The fish viruses. In: Smith KM, Louther MA (eds) Advances in virus research, Vol 12. Academic Press, New York, p 35-101

Manuscript first received: April 1, 1996

Revised version accepted: August 9, 1996 